\title{
Bioinformatics of Nile tilapia (Oreochromis niloticus) lymphocyte cytosolic protein 1 (Icp1) gene
}

\section{Nil tilapiası (Oreochromis niloticus) lenfosit sitosolik protein 1 (Icp1) geninin biyoinformatiği}

\author{
Mehtap Bayır ${ }^{*}$ • Gökhan Arslan² \\ ${ }^{1}$ Atatürk University Agricultural Faculty, Department of Agricultural Biotechnology, Erzurum \\ ${ }^{2}$ Atatürk University Aquaculture Faculty, Erzurum \\ https://orcid.org/0000-0002-7794-1058 \\ iD https://orcid.org/0000-0002-8634-8598
}

\section{How to cite this paper:}

Bayır, M. \& Arslan, G. (2021). Bioinformatics of Nile tilapia (Oreochromis niloticus) lymphocyte cytosolic protein 1 (Icp1) gene. Ege Journal of Fisheries and Aquatic Sciences, 38(1), 63-68. DOI: 10.12714/egejfas.38.1.07

\begin{abstract}
Bioinformatics analysis of lymphocyte cytosolic protein 1 (Icp1) gene in tilapia (Oreochromis niloticus) which is a model organism in experimental studies were completed in this study. For this purpose, characterization and identification of Icp 1 has been completed and ensembl database has been used to design the structure of Icp1 gene. In addition, the chromosome region of tilapia Icp1 and other genes in the same region with Icp1were determined. The chromosome of these genes were detected in zebrafish and human which are identical orthologos of tilapia. Conserved gene synteny designed manually according to these chromosomal regions. In addition, amino acid sequences synthesized by Icp1 gene in some vertebrates were determined using some bioinformatics databases such as UNIPROT, ENSEMBL and NCBI before determine the phylogenetic relationship between these organisms and tilapia. Sequence similarity-identity rate of tilapia Icp1 gene with zebrafish, rainbow trout, human, mouse and platyfish Icp 1/Lcp1 was calculated using BLOSUM62 matrix algorithm. This study is of great importance for the completion of in silico analysis of Icp1 gene in tilapia because it is an aquatic model organism and it has an important place among economic aquaculture species. However this study provides the basic pioneering information for the future studies on molecular stress response in fish.

Keywords: Tilapia, genomic organisation, Icp1, phylogeny

Öz: Bu çalışmada, deneysel çalışmalarda model organizma olarak kullanılan tilapia (Oreochromis niloticus) 'da lenfosit sitozolik protein 1 (Icp1) geninin biyoinformatik çalışmaları yapıımıştır. Bu amaçla, Icp1'in karakterizasyonu ve tanımlaması yapılmış ve Icp1 geninin yapısını tasarlamak için ensembl veri tabanı kullanılmıştır. Ayrıca tilapia Icp/geninin üzerinde yer aldığı kromozom bölgesi ve Icpl geni ile aynı bölgedeki diğer genler ile bu genlerin de yerleri belirlenmiştir. Ayrıca belirlenen bu genlerin kromozom bölgeleri, tilapianın ortologları olan zebra balığı ve insanda da tespit edilmiştir. Bu kromozomal bölgelere göre manuel olarak korunmuş gen yapısı dizayn edilmiştir. Bunlara ilaveten, tilapia ile diğer omurgalılar arasındaki filogenetik ilişkinin belirlenmesi amacıyla UNIPROT, ENSEMBL ve NCBI gibi bazı biyoinformatik veritabanları kullanılarak Icp1 geni tarafından sentezlenen amino asit sekanslarına ulaşılmış ve bu seklanslar kullanılark filogenetik ağaç, Mega programı yardımıyla, Maksimum Olasılık Metodu'na göre oluşturulmuştur. Zebra balığı, gökkuşağı alabalığı, insan, fare ve plati balığı Icp1/Lcp1 ile tilapia Icp1 geninin sekans benzerlik-özdeşlik oranı BLOSUM62 matris algoritması kullanılarak hesaplanmıştır. Bu çalışma, tilapiada Icp1 geninin in-siliko analizinin tamamlanması için büyük önem taşımaktadır. Çünkü tilapia, sucul bir model organizmadır ve ekonomik su ürünleri türleri arasında önemli bir yere sahiptir. Bu nedenlerle, yapılan bu çalışma, balıklarda moleküler stres yanıtı üzerine yapılacak çalışmalar için temel oluşturacak ve her zaman başvurulacak bilgiler sağlamaktadır.

Anahtar kelimeler: Tilapia, genomik organizasyon, Icp1, filogenetik
\end{abstract}

\section{INTRODUCTION}

L-plastin which conserved from yeast to man belongs to the fimbrin family of actin-binding proteins consists of a head domain $(10-\mathrm{kDa})$ and a core domain $(60 \mathrm{kDa})$ (Bredscher, 1981; Lin et al., 1988; Adams et al., 1995). As it is known, cell movement is necessary for the immune system, but how it regulates the movement is much more important as it can be destructive in diseases such as cancer (Goldstein et al., 1985; Lin et al., 1988). Lcp1 was first discovered in neoplastic human fibroblasts. In subsequent studies, this protein was found to increase regulation of many cancer cell lines (Park et al., 1994) and was also highly expressed in normal leukocytes, including macrophages, monocytes and neutrophils. Therefore, studies on Icp1 have been focused on two branches: leukocyte biology of I-plastin and cancer biology of I-plastin. However, the main goal of these two groups is to investigate the effects of actin cell skeleton on regulation and cell mobility (Margaret et al., 2017). This protein has been the subject of many scientific researches (Otsuka et al., 2001; Chung and Deisseroth, 2004; Li and Zhao, 2011) especially because it is a cancer marker, but Icp1 gene regulation, protein function and bioinformatics still need to be studied. 
Tilapia is one of the most aqua cultured fish in tropical and subtropical regions due to its resistance to bad environmental conditions, easy breeding, high adaptability to salty and brackish waters, high plant and animal nutrient resources and rapid growth except from its sensitivity to low water temperature (Donaldson, 1979; Tekelioğlu et al., 1991). Tilapia is cultivated in 75 countries around the world and its most common farming species is Oreochromis niloticus. A large part of tilapia production is in Asia and China takes the first place in the production of tilapia and Philippines follows China (Urch, 1996). Tilapia which is widely farming in many countries, are preferred as a model organism in experimental and genetic studies due to its low chromosome number $(2 n=$ 44 ) and its whole genome sequence is completed (Guyon et al., 2012) as well as being an easily available species (Ergene et al., 1998).

Genetic similarities between species present in all organisms mean that studies on one organism can be used as a data source for other species (Collins et al., 1998). Therefore, in this study, the bioinformatics of Icp1 gene in aquatic model organism, tilapia ( 0 . niloticus) will be completed and leading data will be provided for molecular studies in other fish.

\section{MATERIAL AND METHOD \\ Bioinformatics of lymphocyte cytosolic protein 1 (Icp1) gene}

In order to investigate whether the lymphocyte cytosolic protein 1 (Icp1) gene is a functional or non-functional or pseudogene in tilapia, the cDNA sequence of this gene was reached from the ENSEMBL database and confirmed that the Icp1 gene is a functional gene. Ensemble ID and Uniprot ID of tilapia Icp1 gen was determined as ENSONIG00000016164 and I3KGW3, respevtively and its amino acid number was determined as 619

The conserved gene synteny is designed to detect genes that are conserved in the same way as the orthologues of living organism. For this purpose, we designed the gene synteny by detecting conserved genes in tilapia, zebrafish and human. It was first determined which chromosomes and regions of Icp1 gene were found in tilapia and then other genes in this chromosome were found and their locations were recorded. Then, the chromosomes and locations of these genes detected in zebrafish (Danio rerio) and human (Homo sapiens) which are orthologs of tilapia (Table1). Finaly the conserved gene synteny was designed manually using these datas (Figure 1).

Table 1. The genes used in conserved gene synteny and their location in tilapia, human and zebrafish

\begin{tabular}{|c|c|c|c|c|c|c|c|}
\hline \multirow{2}{*}{ Gene } & \multirow{2}{*}{$\begin{array}{l}\text { Gene } \\
\text { symbol }\end{array}$} & \multicolumn{2}{|c|}{ Tilapia } & \multicolumn{2}{|c|}{ Human } & \multicolumn{2}{|c|}{ Zebrafish } \\
\hline & & Scaffold & Location & Chromosome & Location & Chromosome & Location \\
\hline Integral membrane protein $2 \mathrm{Bb}$ & $i t m 2 b b$ & GL831210.1 & 0.81 & 13 & 48.23 & 9 & 25.33 \\
\hline Laccase domain containing 1 & lacc1 & GL831210.1 & 0.58 & 13 & 43.87 & 9 & 18.57 \\
\hline Leishmanolysin like peptidase & $\operatorname{Im} / n$ & GL831210.1 & 0.47 & 3 & 197.96 & 9 & 38.50 \\
\hline Integrin subunit alpha & itgav & GL831210.1 & 0.51 & 2 & 186.59 & 9 & 11.59 \\
\hline 5-hydroxytryptamine (serotonin) receptor $2 \mathrm{~A}$ & htr2aa & GL831210.1 & 0.96 & 13 & 43.83 & 9 & 25.19 \\
\hline Succinate-CoA ligase ADP-forming beta subunit & sucla2 & GL831210.1 & 0.87 & 13 & 47.74 & 6 & 10.03 \\
\hline Esterase $D$ & esd & GL831210.1 & 1.13 & 13 & 46.77 & 9 & 25.17 \\
\hline Leucine rich repeats and calponin homology domain containing 1 & $\operatorname{Irch} 1$ & GL831210.1 & 1.12 & 13 & 46.55 & 9 & 25.09 \\
\hline Lymphocyte cytosolic protein 1 & Icp1 & GL831210.1 & 0.77 & 13 & 46.12 & 9 & 56.25 \\
\hline CCR4-NOT transcription complex subunit 11 & cnot11 & GL831210.1 & 0.79 & 2 & 101.25 & 9 & 56.23 \\
\hline
\end{tabular}

For determining the phylogenetic relationship between the Icp1/LCP1 genes tilapia (0. niloticus) and zebrafish (Danio rerio), rainbow trout (0. mykiss), brown trout (Salmo trutta), gilthead seabream (Sparus aurata), yellow perch (Perca flavescens), fugu (Takifugu rubripes), pike perch (Sander lucioperca), northern pike (Esox lucius) Norway rat (Rattus norvegicus) mouse (Mus musculus), human (Homo sapiens) CLUSTALW (Thompson et al. 1994) BioEdit program (http://www.mbio.ncsu.edu/bioedit/page2.html) was used. Firstly, the neighbor joining method was applied using the MEGA6 (Tamura et al., 2013) program, then the phylogenetic tree was constructed according to the maximum likelihood method (Kell et al., 2018) (Figure 2). Zebrafish (Danio rerio) fascin actin-bundling protein 2 a (fscn2a) gene was used as the outer group.

Gene structure of tilapia Icp1 which consists of exonintron organization, amino acids produced by exons, 5 'UTR (with TATA box located in this region) and 3'UTR (showing poly $A$ tail in this region) region of the gene, the starting point $(+1)$ of the transcription was designed using data from ensembl database (Table 2). Sequence similarity and identity rate of tilapia Icp1 gene with zebrafish, rainbow trout, human, mouse and platyfish $I c p 1 / L c p 1$ was calculated using
BLOSUM62 matrix algorithm and Bioedit program, CLUSTALW (Thompson et al., 1994) (Table 3).

\section{RESULTS AND DISCUSSION}

\section{Bioinformatics study}

Bioinformatics studies should be completed before experimental studies to understand how the expression of genes changes with various stress factors, in molecular studies, Therefore, this study will provide important bioinformatics for both fish physiology studies and studies on other vertebrates since tilapia is an important model organism. Although there are several studies on tilapia (Urch, 1996; Ergene et al., 1998; Tekelioglu et al., 1991; Kaya and Akbulut, 2012), study on bioinformatics of this model organism are still very poor

\section{Genomic sequences analysis of tilapia Icp1 gene}

Some algorithms and databases such as ENSEMBL, UNIPROT and NCBI databases and BioEdit software, BLOSUM62 matrix program and MEGA6 program were used for in silico analysis such as designing gene structure, phylogenetic analysis, determining similarity and identy between tilapia and some other vertebrates, designing conserved gene in this study. It was seen tilapia Icp1 gene has 15 exons and 14 introns (Table 2). 
Table 2. Tilapia (Oreochromis niloticus) Icp1 gene nucleotide sequence

5 ' gacctcagagtgctctgatcttattacacgcccagcagtaatgaacagagaggcttt gtctgtcaggcaggaagtgaagcacaagcaggaagttttacactggcagaagtgagaact gagcagtttgcttcacagtagalotcagataccatctttgagtttcctctttctttct ctaccacatggtcccgcttacatgctactcggtgctgacaggctttgacttttaaatTT taccacatggtccccgcttacatgctactcggtgctgacaggcttgactttaaatI AATgatgtcttgttttttctcttgtgCCAGTTTCAGGTTCCTCTATTGATTCACGCTTC

AACATGGCCGCCCCACCAATCACTGCAGAGGAGCTGGAGGATCTTAGAGAAGCATTCACT $-\mathrm{N}--\mathrm{M}--\mathrm{A}--\mathrm{A}--\mathrm{P}--\mathrm{P}--\mathrm{I}--\mathrm{T}--\mathrm{A}--\mathrm{E}--\mathrm{E}--\mathrm{L}--\mathrm{E}--\mathrm{D}--\mathrm{L}--\mathrm{R}--\mathrm{E}--\mathrm{A}--\mathrm{E}--\mathrm{T}-$ AAAATTGgtaag ${ }^{\prime}$ N702' tcCagATGTGGACAATGACGGCGTTATCAGCAAGGATGAGCT TGATGCTGTCCTCAAGGCCGCCAACCTTTCACTGCCCGGCTACAGAGTCAGAGAGATGAT $\frac{1}{--\mathrm{D}--\mathrm{A}--\mathrm{V}--\mathrm{L}--\mathrm{K}--\mathrm{A}--\mathrm{A}--\mathrm{N}--\mathrm{L}--\mathrm{S}--\mathrm{L}--\mathrm{P}--\mathrm{G}--\mathrm{Y}--\mathrm{R}--\mathrm{V}--\mathrm{R}--\mathrm{E}--\mathrm{M}--\mathrm{I}}$ CCAGGAGCTGAGCAAGAGCAGCGAAGAGCTCAACTTTGATAAGTTTACTGAAgtggg' N127 CCAGGAGCTGAGCAAGAGCAGCGAAGAGCTCAACTTTGATAAGTTTACTGAA

tccagATTGTCCATGGACTAAAGAGTGCAGAGGTTGCAAAGACCTTCAAGAAAGCAATCA $-\mathrm{I}--\mathrm{V}--\mathrm{H}--\mathrm{G}--\mathrm{L}--\mathrm{K}--\mathrm{S}--\mathrm{A}--\mathrm{E}--\mathrm{V}--\mathrm{A}-\mathrm{-K}--\mathrm{T}--\mathrm{F}--\mathrm{K}--\mathrm{K}--\mathrm{A}--\mathrm{I}--$ CCAAGAAGGAGGGCATCTGTAATGTGGCAGGAACCTCAGAGCAGACTGGCACTCAGCACT T--K--K--E--G--I--C--N--V--A--G--T--S--E--Q--T--G--T--Q--H-CTTACTCAGgtcag ${ }^{\prime}$ N670' tg cagAGGAGGAGAAGGTAGCCTTTGTGAACTGGATCAAT AAAGCTCTGGAGAAGGATCCAGACTGCAAACACGTTCTGCCCATGGATCCTAACACCAAC AAAGCTCTGGAGAAGGATCCAGACTGCAAACACGTTCTGCCCATGGATCCTAACACCAAC GACCTGTTCACCGCCATGGGAGATGGGATCGTTCTCTG $g$ tacg' N1151' gttag TAAAA -D--L--F--T--A--M--G--D--G--I--V--L--C TGATCAACCTGTCTGTAGCCGACACCATCGATGAGAGAACAATCAACAAGAAAAAGCTCA CACCCTTCACCATCCAGg $g$ tgag ${ }^{\prime} \mathrm{N} 98^{\prime}$ a acag GAGAACCTGAACCTGGCCCTGAACTCGG CATCAGCTATTGGCTGCCATGTGGTGAACATTGGAGCTGAGGACCTGAAGGAGGGCAGGC CATCAGCTATTGGCTGCCATGTGGTGAACATTGGAGCTGAGGACCTGAAGGAGGGCAGGC AGCACCTGGTCCTGG GTCTGCTGTGGCAGGTCATCAAGATCGGGCTGTTCGCTGACATC -Q--H--L--V--L--G--L--L--W--Q--V--I--K--I--G--L--F--A--D--IGAGCTCAGCAGGAATGAAGgtgtg ${ }^{\prime}$ N22 $6^{\prime}$ tg 9 CagCTCTGATCGCTCTGCTGCGGGATGG -E--L--S--R--N--E-- A--L--I--A--L--L--R--D--G AGAGAGTCTTGAGGATCTGATGAAACTTTCCCCCGAGGAGCTGCTGTTGCGTTGGGCCAA CTATCACCTGGAGGAGGCGGGCTGTGGCAAGATCAACAACTTCAGCAACGACATCAAG $g t$ CTATCACCTGGAGGAGGCGGGCTGTGGCAAGATCAACAACTTCAGCAACGACATCAAG

gat' N334' tcCagGATTCGAAGGCGTACTACAACCTGCTGAACCAGGTGGCACCCAAAG $-\mathrm{D}--\mathrm{S}--\mathrm{K}--\mathrm{A}-\mathrm{-Y}-\mathrm{-} \mathrm{Y}-\mathrm{-N}--\mathrm{L}-\mathrm{-L}--\mathrm{N}--\mathrm{Q}--\mathrm{V}-\mathrm{A}-\mathrm{A}-\mathrm{P}--\mathrm{K}--$ GAGACGAAGAGGGAATTCCCCCCATTGCCGTTGACATGTCAGGACTCAGGg taag' N349 G--D--E--E--G--I--P--P--I--A--V--D--M--S--G--L--R-

tg CagGAGAAAGACGACCTGAAGCGAGCGGAGCTCATGCTGGACCAGGCCGAAAGGCTCG GGTGCAGACAGTTCGTTATGCCTACAGATGTCGTCCGTGGCAACCCTAAGCTCAACTTGG G--C--R--O--F--V--M--P--T--D--V--V--R--G--N--P--K--I--N--I-CTTTTGTCGCCAATCTGTTCAACAAATACCCGGCTCTGAAGAAGCCAGAGAACCAGGACA $\mathrm{A}--\mathrm{F}-\mathrm{V}-\mathrm{V}-\mathrm{A}--\mathrm{N}--\mathrm{L}--\mathrm{F}--\mathrm{N}--\mathrm{K}--\mathrm{Y}-\mathrm{-P}--\mathrm{A}--\mathrm{L}--\mathrm{K}--\mathrm{K}-\mathrm{P}--\mathrm{E}--\mathrm{N}--\mathrm{Q}--\mathrm{D}--$

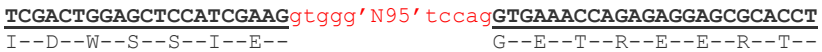
TCAGGAACTGGATGAACTCACTGGGAGTCAACCCTCGTGTAAACCATCTCTACGCgtaag F--R--N--W--M--N--S--L--G--V--N--P--R--V--N--H--L--Y--A

'N123tgCagAGACACTCGACGACGCCTTGGTGATTTCCAGCTGTACGAGAAGATCAAAG TACCAGTGGACTGGGACAGAGTCAACAAACCTCCCTACCCCAAACTGAGCAGCAACATGA V--P--V--D--W--D--R--V--N--K--P--P--Y--P--K--L--S--S--N--M-AGAAGg taca' N563' tccagCTGGAGAACTGTAACTACGCTGTGGAGCTGGGAAAGAAG

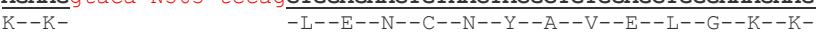
GAGGCCAAGTTCTCTCTGGTCGGCATTGCGGGTCAGGATCTGAACGCAGGGAATCGAACC CTCACCCTCGCTCTGCTCTGGCAGCTCATGAGGAG gtaaa 'N245' CtCagGTACACCCT GAATATTTTGGAGGACCTGGGCGATGGGCAAAAGGTGATCGATGACACCATCGTGTCCTG GAATATTTTGGAGGACCTGGGCGATGGGCAAAAGGTGATCGATGACACCATCGTGTCCTG GGTCAACGACAACCTGACAAGGGCCGGAAAATCCACAATCTCCAGCTTTAAG g taac 'N362' --V--N--D--N--L--T--R--A--G--K--S--T--I--S--S--F--K-

gttagGACGGCTCCATCAGCACCAGCATGCCGGTTCTTGACCTGATCGATGCCATCCAGC $-\mathrm{D}--\mathrm{G}--\mathrm{S}--\mathrm{I}--\mathrm{S}--\mathrm{T}--\mathrm{S}--\mathrm{M}--\mathrm{P}--\mathrm{V}--\mathrm{L}--\mathrm{D}--\mathrm{L}--\mathrm{I}--\mathrm{D}--\mathrm{A}--\mathrm{I}--\mathrm{Q}--$ CTGGATCCATCCGGTACGACCTGCTGAAGACCGAAGACCTGACTGAGGAGGAGAAACTCA P--G--S--I--R--Y--D--I--I--K--T--E--D--I--T--E--E--E--K--I--

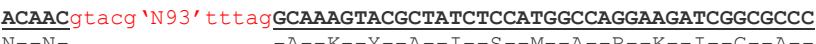
GGGTGTATGCACTCCCCGAGGACCTGGTGGAGGTCAAGCCTAAGATGGTGATGACGGTGT $\mathrm{R}--\mathrm{V}--\mathrm{Y}--\mathrm{A}--\mathrm{L}--\mathrm{P}--\mathrm{E}--\mathrm{D}--\mathrm{L}--\mathrm{V}--\mathrm{E}--\mathrm{V}--\mathrm{K}--\mathrm{P}--\mathrm{K}--\mathrm{M}-\mathrm{-V}--\mathrm{M}--\mathrm{T}--\mathrm{V}--$ TCGCCTGCCTCATGGCTCGTGGCCTGAGGGCCTAAgtcccgtctgtgaagaggagacctC

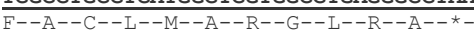

taaagctagcacccaaaggAAATAAgttgctaatgcagaggctccactcacaagttgtggc tttagactgtaaccatttaatgaccagaaatattggatttatgatggcgatacagctgtgg gacacatttcgtaacatctgctggtgattgatgtcttttactcgtgtttcttttaaatgta caatagaaactttgttttattcaaaccaagaagctgaataatcccaagggtcaagtta aacctcacctaaagagttg $3^{\prime}$

*Tilapia (Oreochromis niloticus) Icp1 gene structure. The exons of the I cp1 are shown in capital letters. The starting site of transcription is $+1,5$ UTR sequence and 3 ' UTR sequence are shown in lower case. The first 5 nucleotides and last 5 nucleotides of the introns and the rest of the nculeotides number are given red and lower case. The TATA box and the poly adenylation signal (AATAAAA) are shown in capital letters and painted in blue. Amino acids are shown in capital letters which are placed under exons.Stop codon (TGA) is specified asterisk. 


\section{Orthology of tilapia Icp1 gene with Icp1 genes from other vertebrates}

Protein sequence alignment of each tilapia Icp1 gene with Icp1s from platyfish (Xiphophorus maculatus), zebrafish (Danio rerio), rainbow trout (Oncorhynchus mykiss), human (Homo sapiens) and mouse (Mus musculus) was performed using CLUSTAL W (Thompson et al., 1994), and sequence identity and similarity of tilapia Lcp1 with Lcp1s from other teleost fishes and tetrapods were detected. Tilapia Lcp1 shared highest percentage sequence identity and similarity with fish Lcp1 sequences from tetrapods (Table 3). According to the Table 3, identity-similarity rates of tilapia Icp1 gene were found as $89-95 \%$ with platyfish (Pf), 87-94\% with zebrafish (Zf), $85-91 \%$ with rainbow trout (Rt), $79-88 \%$ with human $(\mathrm{Hu})$ and $79-88 \%$ mouse $(\mathrm{Mo})$.

Table 3. Identity-similarity rate between Tilapia (Ti) and, Platyfish (Pf) Zebrafish (Zf), Rainbow trout (Rt), Human (Hu) and Mouse (Mo)

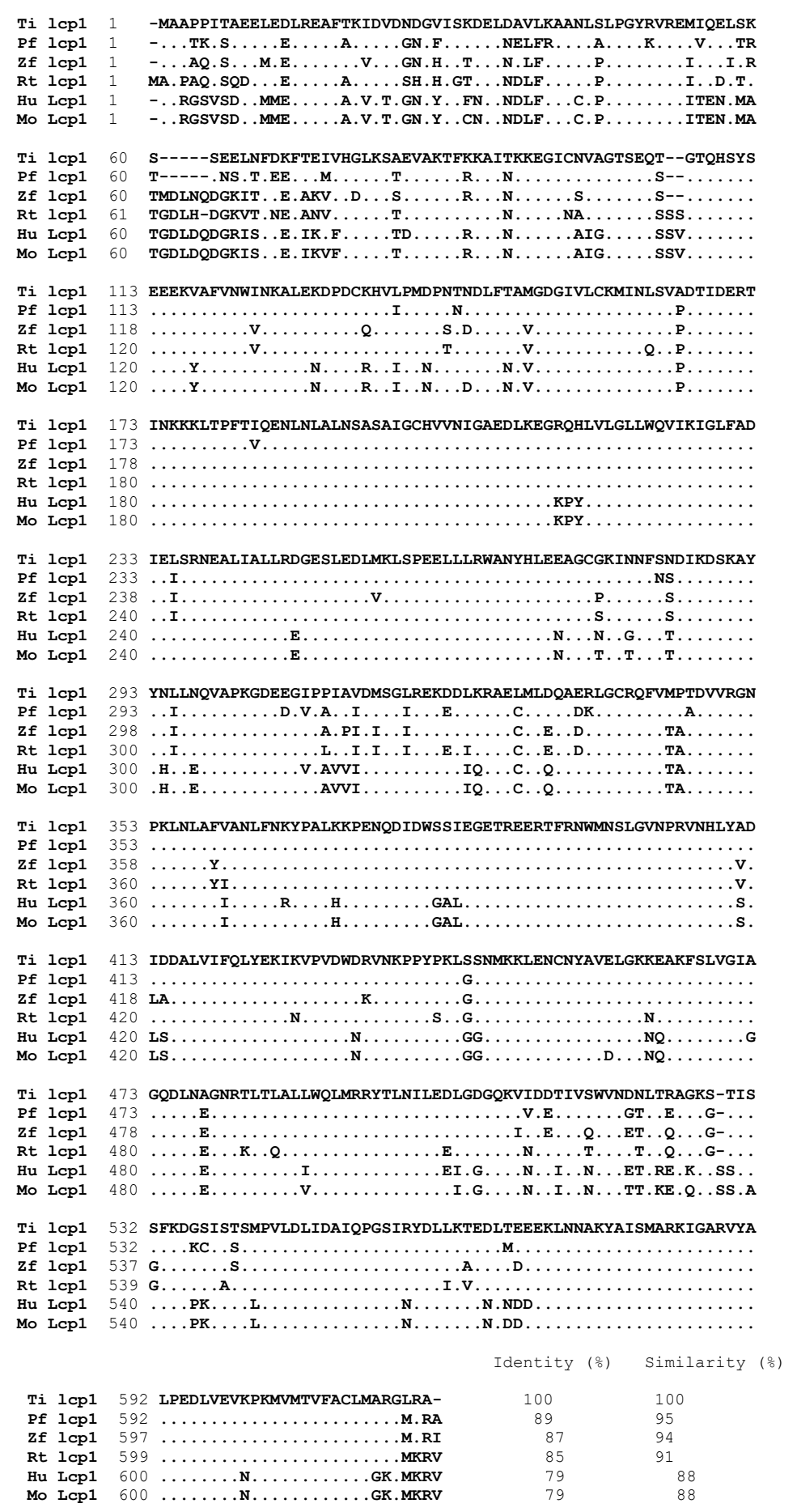

*The dots refer to repeating amino acids and lines represent undetectable amino acids 


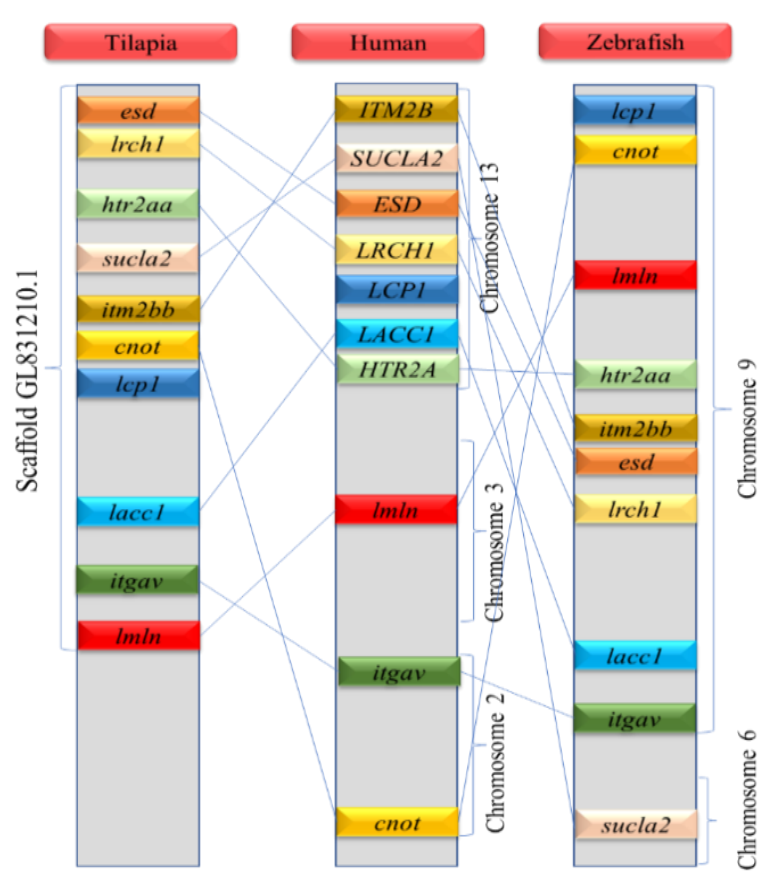

Figure 1. Conserved Gene Synteny of Tilapia Icp1gene

In order to detect the conserved genes of tilapia with zebrafish and human, it was first determined that the Icp1 gene was on the schaffold GL831210.1 and the other genes found in this schaffold were determined from the Ensembl genome database (Table 1). Then, conserved gene synteny was generated manually by region (Chromosome 2, 3 and 13 in human genome and Chromosome 6 and 9 in zebrafish genome) of these detected gene (Figure 1) As it is known, teleost fish have conserved regions for the gene structure of the same gene family, and the conserved gene synteny clearly demonstrates this (Figure 1). It's known that, teleost fish may have two copies of the genes as a result of duplication of the whole genome which are found as a single copy in the other organisms (Amores et al. 1998; Meyer and Schartl 1999; Postlethwait et al. 2000; Braasch and Postlethwait, 2012; Çapan, 2019; Bayır et al., 2020). The results indicate that the Icp1 gene appeared as a result of teleost genome duplication (TGD) in bony fish, but one copy was lost after the TGD. It was seen sometimes in teleost fish such as Bayır et al., (2020) reported that of the medaka, tilapia, stickleback, puffer fish, platyfish, Makobe island cichlid, Midas cichlid, Amazon molly and fugu have a copy of creatine kinase gene (ckma), while zebrafish has two copies of creatin kinase gene, ckma and ckm

A neighbor-joining phylogenetic tree, constructed using sequences of Lcp1/LCP1 from zebrafish, rainbow trout, brown trout, gilthead seabream, yellow perch, fugu, pike, northern pike, Norway rat, mouse and human further supported this orthology (Figure 2). The phylogenetic tree which generated by maximum likelihood method showed that specific fish Lcp1 proteins clustered in distinct clades from tetrapods. The reliability of the tree was evaluated with a 1000 bootstrap replicates (Felsenstein, 1985).

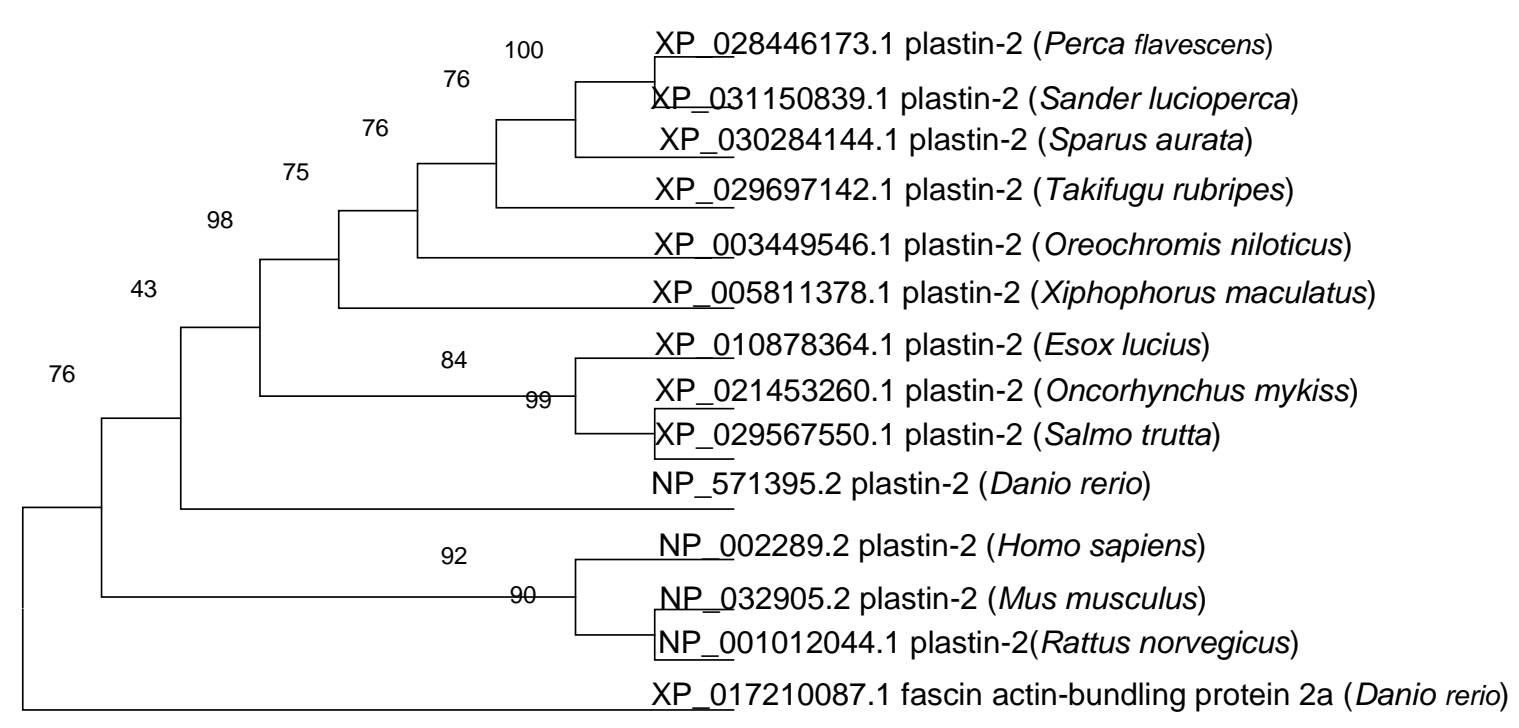

Figure 2. Phylogenetic tree of tilapia Icp1 gene. Phylogenetic relationships between Icp1 sequence from tilapia and the other fish and tetrapods. Tree was constructed using Maximum Likelihood method (Felsenstein, 1989). NCBI accession IDs of the sequences used for phylogenetic tree are given in phylogenetic tree 


\section{ACKNOWLEDGEMENTS}

This article is based on bioinformatics in aquaculture. I would like to thank Prof. Jonothan M. Wright and Prof. Roy G.

\section{REFERENCES}

Adams, A.E., Shen, W., Lin, C. S., Leavitt, J. \& Matsudaira, P. (1995). Isoform-specific complementation of the yeast sac6 null mutation by human fimbrin. Molecular and Cellular Biology, 15, 69-75.

Amores, A., Force, A., Yan, Y.L., Joly, L., Amemiya, C., Fritz, A., Ho R.K., Langeland, J., PrinceV., Wang, Y.L., Westerfield, M., Wang, M.E., Y.L. Postlethwait, J. H. (1998). Zebrafish hox clusters and vertebrate genome evolution. Science, 282 (5394), 1711-1714. DOI: $10.1126 /$ science.282.5394.1711

Bayır, M., Arslan, G., Yıldız Oğuzhan, P. (2020). Characterization, identification and phylogeny of the cretaine kinase (ckma) gene in medaka (Oryzias latipes). Marine Science and Technology Bulletin, 9(1), 15-22.

Braasch, I. \& Postlethwait, J.H.I. (2012). Polyploidy in fish and the teleost genome duplication. In: Soltis, P.S., Soltis, D.E. (eds.), Polyploidy and Genome Evolution, 341-383. DOI:10.1007/9783-642-31442-1_17

Bretscher, A. (1981). Fimbrin is a cytoskeletal protein that crosslinks F-actin in vitro. Proceeeding of the National Academy of Sciences, 78,68496853. DOI:10.1073/pnas.78.11.6849

Chung, I. \& Deisseroth, A.B. (2004). Recombinant adenoviral vector containing tumor-specific L-plastin promoter fused to cytosine deaminase gene as a transcription unit: Generation and functional test. Archives of Pharmacal Research, 27(6), 633-9.

Collins, F.S., Patrinos, A., Jordan, E., Chakravarti, A., Gesteland, R. \& Walters, L. (1998). New Goals for the U.S. Human Genome Project: 1998-2003. Science, 282, 682-689. DOI:10.1126/science.282.5389.682

Çapan, E.C. (2019). Plati balığı (Xiphophorus maculatus)'nda katalaz enzim geninin biyoenformatiği ve doku spesifik dağılımı. Master Thesis. Atatürk University, Erzurum. 77 pp.

Donaldson, E. M. 1979. Hormonal enhancement of growth. Fish Physiology, 8, 456-597.

Ergene, S., Kaya, F., Pekcan, Y. \& Oral, A. (1998). A Karyological Analysis of Oreochromis niloticus (L., 1758) (Pisces, Cichlidae) Used in Aquaculture, First International Symposium on Fisheries and Ecology, 1(10), 2-4, Trabzon.

Felsenstein, J. (1989). PHYLIP-Phylogeny inference package. Cladistics, 5, 164-166.

Goldstein, D., Djeu, J., Latter, G., Burbeck, S. \& Leavitt, J. (1985). Abundant synthesis of the transformation-induced protein of neoplastic human fibroblasts, plastin, in normal lymphocytes. Cancer Res.; 45(11 Pt 2), 5643-7.

Guyon, R., Rakotomanga, M., Azzouzi, N., Coutanceau, J.P., Bonillo, C., D'Cotta, H., Pepey E, Soler, L., Rodier-Goud, M., D'Hont, A., Conte, M.A., van Bers, N. E.M., Penman, D.J., Hitte, C., Crooijmans, R.P.M.A., Kocher, T.D., Ozouf-Costaz, C., Baroiller, J.F. \& Galibert F. (2012). A high-resolution map of the Nile tilapia genome: a resource for studying cichlids and other percomorphs. BMC Genomics,6(13), 222. DOI: 10.1186/1471-2164-13-222
Danzmann who shared their bioinformatics knowledge with me as long as I worked in their laboratories as a post-doc researcher during two years.

Kaya, H., Akbulut, M. (2012). Kurşuna Maruz Bırakılan Tilapia (Oreochromis mossambicus)'nın Eritrosit Morfolojisinde Görülen Değişimler, 22(B), 10 15.

Kell, A.J.E., Yamins, D.L.K., Shook, E. N. \& Norman-Haignere, S.V. (2018). A Task-Optimized Neural Network Replicates Human Auditory Behavior, Predicts Brain Responses, and Reveals a Cortical Processing Hierarchy. Neron, 98(3), 630-644.

Li, J. \& Zhao, R. (2011). Expression and clinical significance of L-plastin in colorectal carcinoma. Journal of Gastrointestinal Surgery, 15(11), 19821988. DOI: 10. 1007/s11605-011-1678-4

Lin, C.S., Aebersold, R. H., Kent, S. B., Varma, M. \& Leavitt, J. (1988). Molecular cloning and characterization of plastin, a human leukocyteprotein expressed in transformed human fibroblasts. Molecular and Cellular Biology, 8, 4659-4668.

Margaret, J.K., Rachel, E.R., Emily A. B., Zachary J. C., Paul J.P., Taylor A. M., Jacek T. \& Elizabeth, E.L. (2017). Targeted deletion of the zebrafish actinbundling protein L-plastin (Icp1). PLOS ONE, 13(1) . DOI:10.1371/journal. pone.0190353

Meyer, A. \& Schartl, M. (1999). Gene and genome duplications in vertebrates: The one-to-four (-to-eight in fish) rule and the evolution of novel gene functions. Current Opinion in Cell Biology, 11(6), 699-704.

$$
\text { DOI:10.1016/s0955-0674(99)00039-3 }
$$

Otsuka, M., Kato, M., Yoshikawa, T., Chen, H., Brown, E.J.Masuho, Y., Omata, M., Seki, N. (2001). Differential expression of the L-plastin gene in human colorectal cancer progression and metastasis. Biochemical and Biophysical Research Communications. 289(4), 876-81.

Park, T.S., Chen, Z.P. \& Leavitt, J. (1994). Activation of the leukocyte plastin gene occurs in most human cancer cells. Cancer Research, 54(7), 17751781.

Postlethwait, J.H., Woods, I.G., Ngo-Hazelett, P., Yan, Y.L., Kelly, P.D., Chu, F., Huang, H., Force, A. H., Talbot, W.S. (2000). Zebrafish comparative genomics and the origins of vertebrate chromosomes. Genome Research, 10,1890-1902. DOI:10.1101/gr.164800

Tamura, K., Stecher, G., Peterson, D., Filipski, A. \& Kumar S, (2013). MEGA6: Molecular Evolutionary Genetics Analysis Version 6.0. Molecular Biology and Evolution,

30 (12): 2725-2729. DOI: 10.1093/molbev/mst197

Tekelioğlu, N., Sarıhan, E., Polat, A. \& Işık, O. (1991). Tilapyaların (Tilapia zilli) Çukurova Koşullarında Sera İçerisinde Kışlatılmaları ve Cinsiyetlerinin Hormonlu Yemlerle Değiştirilmesi. Ege Üni. Su Ür. Fak. Eğitiminin 10. Yılında Su Ürünleri Sempozyumu (12-14 Kasım), İzmir, 534-541 s.

Thompson, J.D., Higgins, D.G. \& Gibson, T. J. (1994). CLUSTAL W: Improving the sensitivity of progressive multiple sequence alignment through sequence weighting, positions-specific gap penalties and weight matrix choice. Nucleic Acids Research, 22(22), 4673-4680. DOI:10.1093/nar/22.22.4673

Urch, M. (1996). Spotligt turns on Tilapia: 'the fish of the 21st Century' Seafood International June pp 25-27. 